\title{
以改革创新精神推动生态文明乡村建设 对中国山东省海阳市生态文明乡村建设的调查与思考
}

\section{Promoting the Construction of Ecological Civilization Countryside with the Spirit of Reform and Innovation}

_ Investigation and Reflection on the Construction of Ecological Civilization Countryside in Haiyang City of Shandong Province, China

山东省海阳市委党校

\section{中国・山东 海阳 265100}

Haiyang Municipal Party School of Shandong Province, Haiyang City, Shandong, 265100, China

\section{王惠荣子 \\ Huirongzi Wang}

【摘 要】自生态文明乡村建设工作开展以来，中国山东省海阳市创新工作机制，取 得了丰硕成果，但还存在诸多困难和问题。因此，应总结当前工作经验，从产业带动、 环境提升、文化传承、移风易俗等方面入手，创新工作理念及方法，推动海阳市新 常态下生态文明乡村建设持续健康发展。

【Abstract】 Since the construction of ecological civilization countryside, Haiyang city has innovated the working mechanism, and achieved fruitful results, but there are still many difficulties and problems. Therefore, we should summarize the current work experience, and innovate the work concept and method from industry driven, environmental improvement, cultural heritage, customs changing and other aspects, so as to promote the sustainable and healthy construction of ecological civilization countryside in Haiyang City of Shandong Province, China.

【关键词】生态文明；乡村建设；路径探析

【Keywords】Ecological civilization; Rural construction; Path analysis

\section{1 引言}

自生态文明乡村建设工作开展以来，中国山东省海阳 市委、市政府制定了“二二四五”的工作机制，各项工作 全面启动，取得了阶段性成果。但是要达到2020年全市732 个行政村全部达到 “美丽乡村” 标准, 还存在诸多困难。 为此, 应多措并举, 以改革创新精神, 推动海阳市新常态 下生态文明乡村建设持续健康发展。

2 海阳市在生态文明乡村建设中创新工作机制, 取得丰硕成果

2.1 理念创新，谋划生态文明乡村建设新蓝图

海阳市创新发展理念, 按照 “城乡统筹、一体发展, 整合资源、集约投入” 的理念，围绕实现全市 “美丽乡 村” 全覆盖的目标, 确立了 “一二四五” 的总体思路。 “一”，即一个总目标：全市所有农村五年内全部达到 “美丽乡村” 硬化、绿化、亮化、净化、美化 “五化” 标准; “二”，即 “美丽乡村” 打造五年 “两步走” 的实 施计划：第一步，前三年集中攻坚期。第二步，后两年扫 尾完善期, 确保 2020 年全面实现 “美丽乡村”全覆盖。 “四”, 即四项保障措施: 一是强化人力保障, 二是整 合财力保障, 三是秩序氛围保障, 四是督查考核保障; “五”, 即生态文明乡村建设的五大重点任务: 农村人居 环境综合整治、农村改则、壮大农村集体收入、精准扶贫
和转变农民生活方式。

2.2 组织创新，打造生态文明乡村建设新机制 组织创新，打造生态文明乡村建设新机制。 2.3 政策创新，提供生态文明乡村建设新动力

海阳市成立了由市委副书记任总指挥长的生态文明乡 村建设指挥部, 从各单位抽取精干力量充实指挥部力量, 加强总体协调、加大督导督查, 统一组织考核, 统筹推进 各项工作。专门出台涉农资金整合工作实施方案，建立以 镇村自筹为主, 市级奖补、对上争请、部门帮扶、社会参 与为辅的多元化投入机制。

2.4 工作创新，提供生态文明乡村建设新保障

实行棋盘式、网格化、市场化、立体化和多样化的考 核方式。由于管理细致、统筹领导, 海阳市美丽乡村建设 经验多次受到烟台市委市政府肯定，工作成效显著。

2.5 产业创新，增加生态文明乡村建设新内涵

按照扶贫工作重点村的地理特点、资源优势等自然条 件确定重点扶贫产业，坚持因村因人制宜，坚持 “一把钥 匙开一把锁” , 通过实施 “六子工程” , 做实做细做好扶 贫工作：在发展特色农业方面，特色引出 “好法子”，在 发展乡村旅游方面，旅游带动“新路子”，在发展光伏项 目方面, 能源亮出 “富点子”, 在产业促进就业方面, 产 业鼓起 “钱袋子”，在教育帮扶脱贫方面, 助学拔掉 “穷 
根子”，在资金投入收益方面，多种形式 “收份子”。

\section{3 生态文明乡村建设中暴露出的突出问题和困难}

目前已经打造的美丽乡村是总体发展比较好的示范 村, 今年起要大面积铺开生态文明乡村建设, 面临的就是 一些问题村, 工作越到后期, “难啃的硬骨头” 越多, 这 些村存在一些突出问题和困难。

\section{1 集体经济薄弱，建设资金不足}

近年来, 海阳市财政对生态文明乡村建设的投入, 在 绝对量上一直保持着增长的态势, 但分配到每个村就相对 不足, 难以满足建设需要。

\section{2 两委班子软弱, 战斗能力不强}

一是班子不团结, 凝聚力差难以形成合力。二是部分 村干部文化素质比较低, 对农村、农业新形势、新发展和 新变化, 接受能力弱。

\section{3环境整治乏力，打造标准不高}

在环境综合整治方面一些村存在打造 “标准低、档次 低、效果差” 的现象。一些乡镇为完成任务, 重点打造的村庄 过多偏重于户数较少的村, 虽然打造起来简单, 但是存在亮点 不亮，带动和引领其它村庄发展方面作用不明显的情况。

\section{4 村民思想落后, 文化引领不强}

部分村民还存在着过去的陈旧思想, 参与热情不高, 认为抓生态文明建设就是政府的事, 存在 “等、靠、要” 思想, 缺乏积极性、参与性、主动性。一些村把善行义举 “四德榜” 的建设更多的作为一项考核任务完成, 没有认 真发挥其打造道德高地, 催人向善, 宣传正能量的作用。

\section{4 以改革创新精神推动生态文明乡村建设}

海阳市美丽乡村建设要以 “产业美、生活美、环境 美、人文美” 为立足点, 配强农村领导班子, 以改革创新 精神推动生态文明乡村建设。

\section{1 产业带动, 夯实发展后劲}

(1)持续发力, 做好全域旅游业。“旅游+农业”是推动 农业由传统模式向观光休闲模式的全域旅游转化的有效途 径, 在大力发展精品采摘、农事体验等活动的同时, 延长 农业产业链，因地制宜打造乡村旅游线路。一是建设生态 游、农家乐、采摘园等旅游项目, 由村集体进行规划、打 造, 通过村承接客源、对接农户, 增加村集体收入。二是 依托特色农产品, 组织成立特色果蔬种植基地, 承接现有 旅游资源, 加快电子商务发展。三是开发集养殖、垂钓、 休闲等为一体的露营旅游基地, 拓宽集体增收渠道。四是 鼓励村集体投资兴办超市、餐饮、农资等服务项目, 采取自 主经营、管理服务等形式增加集体收入。(2)整合资源, 做好 优势产业再开发。摸清各村集体土地、山岗、水域等资源 现状，对村集体可支配的土地等资源进行统一租赁、发包 或规划开发。同时, 依法推进农村土地流转, 提高村集体 收入。(3)强强联合, 开创村企合作新局面。鼓励村级组织 与农资企业联合办社, 通过以集体资源、资产或者资金入 股合作社的方式，直接参与合作社的经营管理分红获利。

\section{2 以点带面, 促进环境提升}

(1)加大生态环境综合整治力度。现阶段已进行的环 境整治还不够全面, 要在抓好重点村、重点道路的同时,
以点带面, 产生 “蝶变效应”。一是抓好村庄环境综合整 治。二是做好路域环境综合整治。三是推进水域环境综合 整治。(2)高效运转垃圾一体化全覆盖处理体系。一是优化 并加强保洁员队伍管理。二是切实提升中转站运转效率。 三是创新模式开展一体化处理。(3)深入推进农村改则。一 要提高思想认识, 营造良好氛围, 动员群众积极主动参与 改则建设。二要因地制宜, 准确谋划, 变全覆盖为以点带 面、分类实施。对具备各方面改则条件的农户全面改, 并 给予全额补贴, 以调动农户的积极性。

\section{3 突出特色, 注重文化传承}

(1)将生态建设与历史文化传承相结合, 突出文化特 色。不断提升农村文化氛围, 是生态文明乡村建设的精神 支撑。要打造海阳独特的文化品牌, 应将民俗与现代结 合、历史与现实结合, 用独一无二的文化魅力来凝聚民 心。挖掘保护农村传统民俗文化和注重发掘农村历史, 对山东省第一批传统村落和正在申报传统村落的村进行统 一规划打造, 建成具有海阳特色的乡村民俗旅游村庄。(2) 在美丽乡村建设过程中弘扬中华优秀传统文化。将中华优 秀传统文化的孝、悌、忠、信、礼、义、廉、耻等内容融 入乡村景观打造, 让村民在潜移默化中提升道德修养。(3) 在美丽乡村建设过程中突出社会主义核心价值观内容。在 景观打造中, 要将社会主义核心价值观内容作为重点, 特 别是爱国、敬业、诚信、友善的个人层面价值观融入新时 代、新内容, 与海阳市地雷战等红色文化相结合, 突出强 调海阳人民勤劳朴实、勇敢智慧的性格特点, 以及拼搏、 担当、创新、卓越的海阳精神。

\section{4培育新风，增进人文和谐}

(1)树立环境整治正面典型。做好 “四德榜” 建设, 提高群众上榜率, 引导村民逐步形成 “爱护环境, 保持卫 生” 的意识和生活习惯。(2)加大文化惠民力度。提供各类 适合镇村文化发展的文化产品, 文化大院、农家书屋、文 体广场建设, 村村有村级健身队伍, 让村民都能参与到健 康、文明的生活中, 形成积极向上的文化氛围。(3)推进农 村健康文明生活方式转变。紧密结合各村镇的特色文化, 在村民中培养文艺骨干, 组建宣传队、秧歌队等群众业余 文化组织。把美德故事、身边的好人好事、道德模范的先 进事迹编成地方剧、情景剧在村民中心、文化广场进行演出。

\section{5 配强班子，发挥堡垒作用}

(1)优化干部队伍结构。选优配强村党组织领导班子, 特别是党支部书记。我们在调研中发现, 凡是在村工作中 想法多、工作成绩突出的党支部书记, 都有在大城市或发 达地区工作的经历。因此, 要结合村级支部换届, 将这类 “能人” 吸引到村支部中来, 提升党支部的战斗力。(2)加 强党员队伍建设。着重培养在农村工作中能带头致富的人 进入党员队伍, 打破一些村的家族垄断势力, 切实提高基 层党员讲政治、讲党性的自觉意识, 增强农村干部干事创 业、为民服务和维护农村稳定的能力。(3)加大村级组织投 入。设立专项资金, 加强对村级组织运转经费补贴力度, 提高村干部报酬待遇, 加大对办公经费和服务群众经费的 支持力度, 确保基层党组织有钱办事。 